\title{
Pak Daeng`s Angklung as a Learning Media for Keroncong Music Rhythm at SMP Negeri Unggulan Sindang, Indramayu
}

\author{
Uus Karwati*, Yudi Sukmayadi, Budi Hartiana Sudradjat \\ Arts of Education \\ Universitas Pendidikan Indonesia \\ Bandung, Indonesia \\ *karwatiuus@gmail.com, yudi.sukmayadi@upi.edu, budi.hartiana@yahoo.co.id
}

\begin{abstract}
This article entitled is Pak Daeng`s Angklung as a Learning Media for Kroncong Music Rhythm at SMP Negeri Unggulan Sindang, Indramayu. Pak Daeng's Angklung is the name of the angklung ensemble which is tuned in the Western music scale. In schools, the use of angklung can be developed as a learning media, to learn various aspects and other elements of music, even introducing the rhythm of a certain music genre. This study applies a qualitative method with the Design Based Research (DBR) approach. with the following steps: identification and problem analysis (determining the rhythmic pattern of keroncong music rhythms, and the angklung instrument used); make design and lesson plans, about keroncong music rhythms in 8 meetings; reflect on learning which results in realizing that learning is carried out in 3 cycles; The evaluation results show that $95 \%$ of students understand the material and $5 \%$ (lacking, because of low musicality). The research findings state that: Pak Daeng's angklung can be used as a media for learning keroncong music rhythms, through the learning results, students are able to fundamentally increase their knowledge and understanding of keroncong music rhythms, and able to understand the basic skills of playing keroncong music rhythm well.
\end{abstract}

Keywords-Pak Daeng`s angklung, learning media, keroncong music rhythm

\section{INTRODUCTION}

Professionalism of a teacher is a prerequisite for achieving educational success. The professional teachers mentioned above are people who are experts in their fields. Called an expert, one of his characteristics is being able to overcome various obstacles and hurdle. Therefore, from time to time, a teacher must always be innovative, have the power to explore and improvise in responding to the conditions in the school where they teach. It is certain that in Indonesia, the supporting facilities in each school are not evenly distributed.

The fact that the facility is incomplete, I met as a researcher or music teacher at SMP Negeri Unggulan Sindang, Indramayu. There is a complete provision of music equipment, still being pursued by the school, and has not been well implemented, considering that the availability of school funds is still prioritized to support other, more important needs.

In learning the art of music, the existence of instruments is a must-have factor, because learning the art of music requires a musical instrument. Here musical instruments serve as a media of learning, namely various types of components in the environment of students, which can motivate students to learn [1]. It can be assumed that learning the art of music without a musical instrument can create demotivation.

In this research, the use of Pak Daeng's angklung music device, to be one solution. This is supported by several reasons, namely:

- This instrument has a Western musical tonality standard which corresponds to the tonality in keroncong music, making it easier for teachers to teach them to students.

- Angklung has a variety of different devices which functionally musically, it can represent several musical functions of keroncong musical instruments,

- Playing angklung does not require special skills, like other western musical instruments. Only by shaking it with your hand will the angklung produce the desired tone. With the simplicity and convenience of angklung, then the rhythm of keroncong music will be easily imitated by the sound of angklung,

- Angklung can accompany various musical genres, including pop music genre or keroncong music genre.

\section{METHODS}

This research used descriptive qualitative method. With this method, researchers can understand, interpret, and rebuild concepts in depth. the data obtained from this method is not in the form of numbers, but in the form of words, pictures, graphs from the results of observations, interviews, documentation and literature studies. 
The theory for qualitative researchers will function, as a provision to be able to understand the social context more broadly and deeply. However, in conducting qualitative research, researchers must be able to let go of this theory and not be used as a guide for interviews and observations [2].

This research was conducted at SMP Negeri Unggulan Sindang Indramayu, which is located on Jalan Terusan Sindang KM. 03, Indramayu.

The method used in this research is the DBR (Design Based Research) approach. The research began when the researcher found a problem, regarding the development of keroncong music, which was increasingly not interested by students.

In fact, keroncong music has the uniqueness of each musical instrument, especially in how it plays.

In a journal entitled Design Based Research and Educational Technology: Rethinking Technology and Research Agenda (2008, pp. 29-40), explained that research using DBR is divided into 4 stages, namely:

- Problem identification and analysis. Identify the problem to be researched, the causes, effects, and solutions the problem.

- Designing solutions, Design solutions to problems with the program that will be carried out in the learning process, as well as preparation of the place, students, time and others.

- Repetitive cycle in testing and design refinement. Three cycles were defined, namely the introduction cycle, the training cycle, and the application cycle to the song.

- 4) Reflection to produce design and implementation principles. Reflections on informants who are involved in the education of keroncong music and angklung music to get a learning model suitable for students [3].

Data collection techniques are the most important step in research. Because the main purpose of research is to get the data that researchers need. Without knowing data collection techniques, then the researcher will not get data that meets the established data standards [4]. Data collection was carried out by means of observation, interview and literature study techniques.

One of the functions of the DBR is to develop a teaching material. The use of the DBR approach is in accordance with the research that will be developed. After the end of the research process in the field and it is declared complete, Researchers will evaluate and reflect to get results and conclusions. The following are the steps or the concept map for the research to be carried out (figure 1).

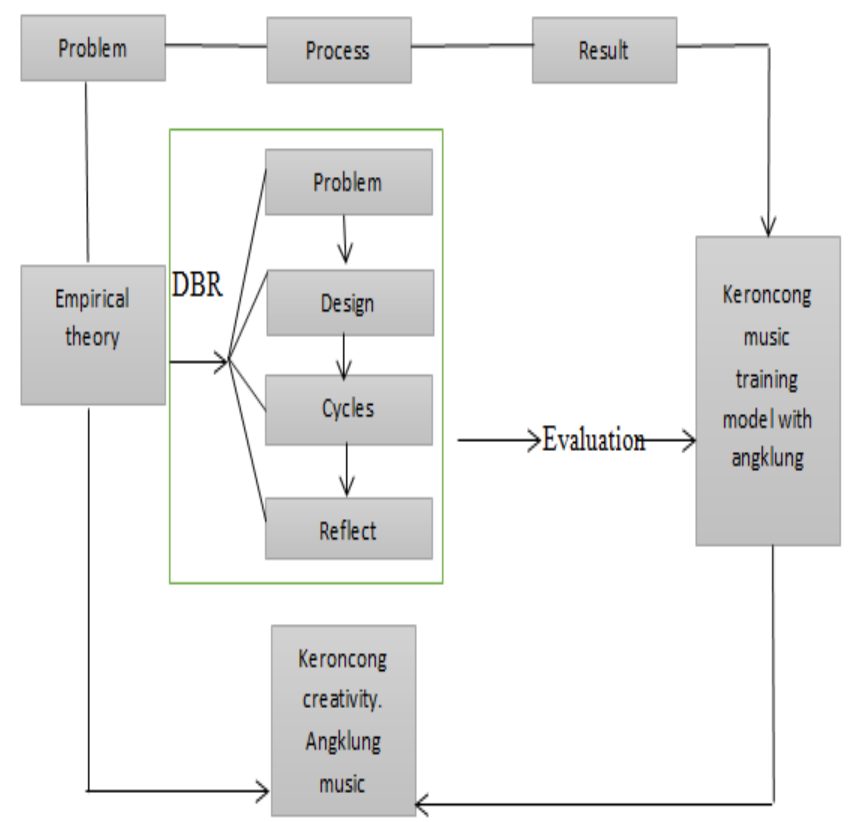

Fig. 1. Research concept map.

\section{RESULTS AND DISCUSSION}

Based on preliminary observations, there are several indications of adequate angklung instruments to be used as a medium in learning keroncong music, namely: akompanyemen angklung, co-akompanyemen, bamboo bass hit, and angklung gambang, the musical function can replace cuk, cak, contra bass, and cello.

In this research will focus on these four musical instruments, as a media in the keroncong music learning model. I hope, keroncong music can be developed and studied through Pak Daeng's angklung music media, in the learning process in the classroom.

Learning keroncong music in the students of SMP Negeri Unggulan Sindang Indramayu is something new. There are indications that, to learn music in practice is very limited by the ability of students in terms of mastery of rhythm. To overcome these students' abilities, Researchers seek to provide knowledge of rhythmic patterns by taking the following steps:

- The researcher shows the keroncong music video to be listened to and carefully,

- Identify keroncong musical instruments,

- Analyzing rhythmic patterns,

- Analyzing the function of rhythmic patterns on keroncong musical instruments and

- Classify the form of the easiest rhythmic patterns to the more difficult ones. 
After students understand and can play rhythmic patterns of keroncong music, Then the students apply the rhythmic pattern to angklung music.

\section{A. Angklung Music}

Angklung is a traditional musical instrument originating from West Java. Angklung is made of special bamboo keys. Since November 16, 2010, angklung has been recognized worldwide and inaugurated by UNESCO as an intangible world heritage originating from Indonesia. Since then, angklung has developed quite rapidly.

Pak Daeng angklung, also known as diatonic angklung, because the notes are adjusted to the diatonic tone scale (i.e. do, re, mi, fa, sol, la, si, do). To make it easier to play angklung notes, Pak Daeng gives a sign / code, which is applied to diatonic angklung by using a numeric code. For the melody angklung, the numbers from no.0 s.d. 30, And for big angklung (party bass) it is marked according to the tone played (notes $\mathrm{G}$, G \#, A, A \#, B, C, C \#, D, D \#, E, and F). The accompaniment angklung has a chord shape consisting of three or four tubes [5]. For more details, it can be seen in the figure 2 .

\begin{tabular}{|c|c|c|c|c|c|c|c|c|c|}
\hline No. Angklung & $\mathbf{0}$ & $\mathbf{l}$ & $\mathbf{2}$ & $\mathbf{3}$ & $\mathbf{4}$ & $\mathbf{5}$ & $\mathbf{6}$ & $\mathbf{7}$ & $\mathbf{8}$ \\
\hline Tone & Fis & $\mathrm{g}$ & Gis & A & Ais & b & $\mathrm{c}^{4}$ & cis $^{4}$ & $\mathrm{~d}^{4}$ \\
\hline Notation & 4 & 5 & 5 & 6 & 8 & 7 & 1 & $x$ & 2 \\
\hline
\end{tabular}

\begin{tabular}{|c|c|c|c|c|c|c|c|c|c|}
\hline No. Angklung & 9 & 10 & 11 & 12 & 13 & 14 & 15 & 16 & 17 \\
\hline Tone & dis $^{\mathrm{t}}$ & $\mathrm{e}^{\mathrm{t}}$ & $\mathrm{f}$ & fis $^{\mathrm{t}}$ & $\mathrm{g}^{\mathrm{t}}$ & gis $^{\mathrm{t}}$ & $\mathrm{a}^{\mathrm{t}}$ & ais $^{\mathrm{t}}$ & $\mathrm{b}^{\mathrm{t}}$ \\
\hline Notation & $Z$ & 3 & 4 & 4 & 5 & 5 & 6 & 8 & 7 \\
\hline
\end{tabular}

\begin{tabular}{|c|c|c|c|c|c|c|c|c|c|}
\hline No. Anglklung & 18 & 19 & 20 & 21 & 22 & 23 & 24 & 25 & 26 \\
\hline Tone & $\mathrm{c}^{2}$ & cis $^{2}$ & $\mathrm{~d}^{2}$ & dis $^{2}$ & $\mathrm{e}^{2}$ & $\mathrm{f}^{2}$ & $\mathrm{fis}^{2}$ & $\mathrm{~g}^{2}$ & gis $^{2}$ \\
\hline Notation & $i$ & $\dot{X}$ & $\dot{2}$ & $\dot{z}$ & $\dot{3}$ & $\dot{4}$ & $\dot{4}$ & $\dot{5}$ & $\dot{5}$ \\
\hline
\end{tabular}

\begin{tabular}{|c|c|c|c|c|}
\hline No. Angklung & 27 & 28 & 29 & 30 \\
\hline Tone & $\mathrm{a}^{2}$ & ais $^{2}$ & $\mathrm{~b}^{2}$ & $\mathrm{c}^{3}$ \\
\hline Notation & $\dot{6}$ & $\dot{8}$ & $\dot{7}$ & $1^{\prime \prime}$ \\
\hline
\end{tabular}

Fig. 2. Tone numbering function in music Pak Daeng's Angklung.

Figure 2 describes the sequence of melodic angklung numbers, translated into numerical notation, with a diatonic chromatic scale on the Pak Daeng`s angklung system.

While the notation figure 3, explains the sequence of melodic angklung numbers applied to the block notation scale.

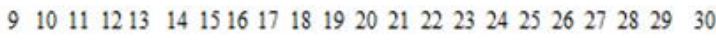

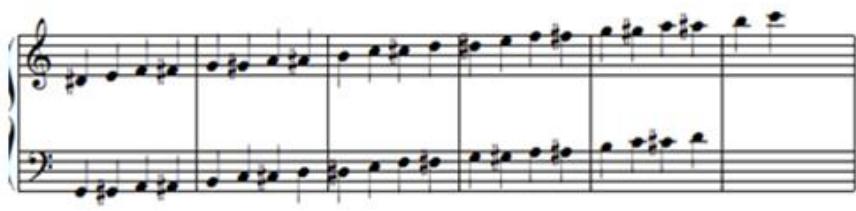

$\begin{array}{llllllll}1 & 2 & 3 & 4 & 5 & 6 & 7 & 8\end{array}$

Fig. 3. The arrangement of tones and angklung numbers on block notation.

Angklung Pak Daeng (diatonic angklung), consists of two large groups [6], namely:

- Angklung melody, consisting of a small melody and bass party.

- Angklung pengiring, yang terdiri dari bas pukul, akompanyemen, ko-akompanyemen, dan angklung gambang.

Pak Daeng's angklung music, used as a media in this learning model, there is a similarity in function such as in keroncong music. The function of the bass which is identified with the bass striking bamboo, the cuk with the akompanyemen, the cak with the co-akompanyemen, and the cello with the angklung gambang.

\section{B. Keroncong Music}

Keroncong music was introduced and developed by the Portuguese in the 16th century, precisely in 1512. In the beginning, keroncong is music that comes from the sound of the musical instrument itself, namely cuk (kencrung), which makes a crong-crong sound on the instrument [7].

In this research, the function of keroncong rhythmic patterns will be applied to accompanying angklung music.

To achieve competence in playing keroncong musical rhythms, using angklung media, the researcher analyzes rhythmic patterns on keroncong musical instruments. then applied to angklung music. The rhythmic pattern of keroncong music has various patterns, depending on the tempo of the song to be played. Figures 4,5 and 6 are a variety of rhythmic patterns that are owned by keroncong musical instruments.

\section{1) Bass rhythmic pattern}

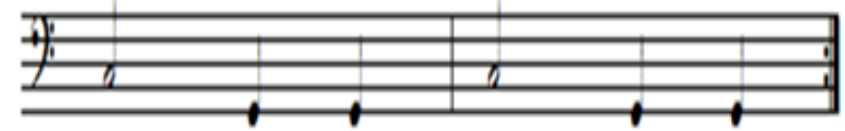

Fig. 4. Example of a rhythmic pattern of Bass betot. 


\section{2) Cuk and cak rhythmic patterns}

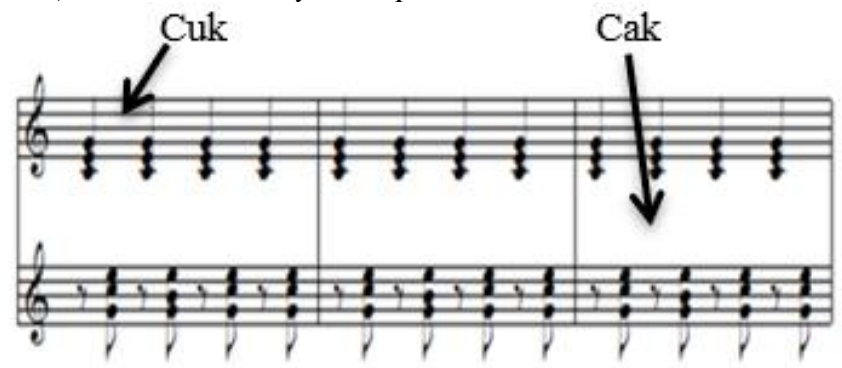

Fig. 5. Examples of cuk and cak rhythmic patterns.

\section{3) Picked cello rhythmic pattern}

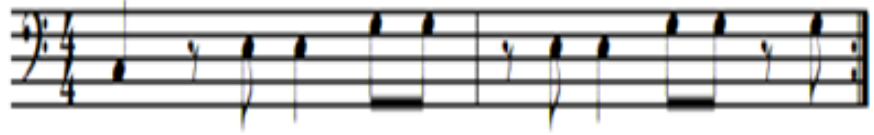

Fig. 6. Examples of plucked cello rhythmic patterns.

Implementation of the learning process in the classroom, will begin with learning the simplest rhythmic patterns and easy for students to follow. The rhythmic pattern learning practice will begin with the vowel sound, And followed by all students repeatedly until understood. After being able to be imitated by a vowel sound onomatopoetic [8]. then students are assigned to imitate the rhythmic pattern with clapping hands, until you can feel the rhythmic harmony between the vowels and the clapping of the hands. And the next step, the rhythmic pattern will be applied to angklung music.

Considerations for a teacher to think about, when choosing a learning model to use, must be adjusted to the competence and objectives to be achieved. In connection with that matter, The discussion in this research will be focused on the results obtained. Thus, the results obtained from this study are:

- Students are able to change the knowledge they understand, especially regarding keroncong music and angklung music, so that it will lead to motivation in students, and the process of teaching and learning activities will be more active and enjoyable. The implementation of this learning is carried out in cycle 1 , the first meeting and the second meeting.

- Students understand and are able to play keroncong music rhythms using the angklung musical instrument. This learning will be carried out in cycle 2, the third meeting until the fifth meeting.

- Students are able to sing a song that is played with a keroncong rhythm using angklung media. This learning is carried out in cycle 3 , the sixth meeting to the eighth meeting.
Figure 7 is the result of the final assessment of knowledge and skills in playing the keroncong rhythmic pattern.

\begin{tabular}{|c|c|c|c|c|c|c|c|c|}
\hline \multirow{2}{*}{ No } & \multirow{2}{*}{ Student's Name } & \multirow{2}{*}{$\begin{array}{l}\text { Musical Instrument } \\
\text { Name }\end{array}$} & \multicolumn{6}{|c|}{ Assessment } \\
\hline & & & Pattern & SB & $\mathrm{B}$ & $\mathrm{C}$ & $\mathrm{K}$ & SK \\
\hline \multirow[t]{3}{*}{1} & Ivan & Bas betot & 1 & $\checkmark$ & & & & \\
\hline & & & 2 & $\checkmark$ & & & & \\
\hline & & & 3 & $\checkmark$ & & & & \\
\hline \multirow[t]{3}{*}{2} & Zafira & Cuk & 1 & 8 & & & & \\
\hline & & & 2 & $\checkmark$ & & & & \\
\hline & & & 3 & $\checkmark$ & & & & \\
\hline \multirow[t]{3}{*}{3} & Lulu & Cak & 1 & 7 & & & & \\
\hline & & & 2 & & $\checkmark$ & & & \\
\hline & & & 3 & 8 & & & & \\
\hline \multirow[t]{2}{*}{4} & Haikal & Cello petilk & 1 & 8 & & & & \\
\hline & & & 2 & & $\checkmark$ & & & \\
\hline 5 & windri & Anglelung melodi & - & $\checkmark$ & & & & \\
\hline 6 & $\operatorname{Iman}$ & Angklung melodi & & $\checkmark$ & & & & \\
\hline 7 & \begin{tabular}{|l|} 
Tazqia \\
\end{tabular} & \begin{tabular}{|l} 
Angklung melodi \\
\end{tabular} & & $\checkmark$ & & & & \\
\hline 8 & Zakiatul & Angklung melodi & & 7 & & & & \\
\hline 9 & Nopita & Angklung melodi & & & r & & & \\
\hline 10 & Rifat & Anglilung melodi & & $\checkmark$ & & & & \\
\hline 11 & Maysayu & Angiklung melodi & & & & 7 & & \\
\hline 12 & \begin{tabular}{|l|} 
Tasya \\
\end{tabular} & \begin{tabular}{|l} 
Anglelung melodi \\
\end{tabular} & & & $\checkmark$ & & & \\
\hline 13 & \begin{tabular}{|l|} 
Winda \\
\end{tabular} & Angklung melodi & & & d & & & \\
\hline 14 & Nurhidayah & Angklung melodi & & & 7 & & & \\
\hline 15 & Vierly & Angklung melodi & & & 7 & & & \\
\hline 16 & Bilqis & \begin{tabular}{|l} 
Angklung melodi \\
\end{tabular} & & 7 & & & & \\
\hline 17 & Fadhilah & Angklung melodi & & & 8 & & & \\
\hline 18 & Alya & Anglifung melodi & & & 8 & & & \\
\hline 19 & Alifa & Angklung melodi & & & $\checkmark$ & & & \\
\hline 20 & Indah sari & 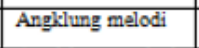 & & & 8 & & & \\
\hline 21 & galya & Anghlungmelodi & & & 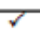 & & & \\
\hline
\end{tabular}

Fig. 7. Final assessment results of musical instruments and rhythmic patterns.

Figure 7 shows the results of the final assessment of knowledge and rhythmic patterns of keroncong music rhythms, as follows: 20 students (95\%) were able to understand knowledge and play rhythmic keroncong music patterns. And 1 student $(5 \%)$ is less able to master the skill of playing the keroncong rhythmic rhythmic pattern, due to the musicality factor, which is owned by these students.

\section{CONCLUSION}

The application of the Student Teams Achievement Division (STAD) cooperative learning model, in cycle 1, cycle 2 , and cycle 3 , shows a significant increase in student learning activities. The increase in student learning activities can be seen from the student observation sheets based on the implementation of learning activities.

In cycle 1, speech in the class, discussion, evaluation, and demonstration activities encourage students to increase knowledge, about keroncong music and angklung music. In 
cycle 2, group presentation activities encourage students to learn and master the rhythmic patterns of keroncong music which are applied through Pak Daeng's angklung music. And in cycle 3 the students succeeded in implementing the keroncong music rhythm in a song using Pak Daeng's angklung music media.

Thus it can be concluded, that the results of the learning model of keroncong music rhythm through Pak Daeng's angklung music media can increase the knowledge and skills of students significantly.

\section{REFERENCES}

[1] D.J. Priansa, Pengembangan Strategi Dan Model Pembelajaran: Inovatif, Kreatif, dan prestatif dalam memahami peserta didik. Bandung: Pustaka Setia, 2017.
[2] Sugiyono, Metode Penelitian Pendidikan Pendekatan Kuantitatif, Kualitatif, dan RD. Bandung: Alfabeta, 2018.

[3] T. Amiel and T.C. Reeves, "Design-based research and educational technology: Rethinking technology and the research agenda," Journal of educational technology \& society, vol. 11, no. 4, pp. 29-40, 2008.

[4] Sugiyono, Statistik Untuk Penilaian. Bandung: Alfabeta, 2010.

[5] J. Masunah, R. Milyartini, O. Yukarya, U. Karwati and D. Hermawan, Pendidikan Kesenian, Metodologi Pengajaran Angklung di Jawa Barat, Buku ke-2. Bandung: IKIP, 1999.

[6] O.A. Wiramihardja, H. Waluyo and G. Mancacaritadipura, Panduan bermain angklung. Jakarta: Pusat Penelitian dan Pengembangan Kebudayaan, Badan Pengembangan Sumber Daya Kebudayaan dan Pariwisata, Kementerian Kebudayaan dan Pariwisata, 2010.

[7] S. Harmunah, Musik Keroncong (Sejarah, gaya, dan pengembangan) Yogyakarta: Pusat Musik Liturgi, 1987.

[8] D. Mack, Sejarah Musik (Jilid 4). Yogyakarta: Pusat Musik Liturgi, 1995. 